\title{
Consumo e Fermentação Ruminal de Proteínas em Função de Suplementação Alimentar Energética e Protéica em Novilhos ${ }^{1}$
}

\author{
Natália Guarino Souza Barbosa², Rogério de Paula Lana ${ }^{3}$, Gulab Newandram Jham, \\ Arnaldo Chaer Borges ${ }^{5}$, Antônio Bento Mâncio ${ }^{3}$, José Carlos Pereira ${ }^{3}$, Juliana Silva Oliveira ${ }^{6}$
}

\begin{abstract}
RESUMO - Objetivou-se analisar o efeito de suplementação energética sobre o consumo e a fermentação ruminal de proteínas em dois níveis de proteína dietética (6 e 20\%). Quatro novilhos mestiços fistulados no rúmen foram utilizados em um quadrado latino e os tratamentos arranjados em um fatorial $2 \times 2$, em que as dietas testadas constituíram-se de: A. só feno; B. feno $+2,8 \mathrm{~kg}$ de farelo de soja; C. feno $+2,8 \mathrm{~kg}$ de fubá de milho; e D. feno $+2,8 \mathrm{~kg}$ de farelo de soja $+2,8 \mathrm{~kg}$ de fubá de milho. Foram realizados quatro períodos experimentais constituídos de 18 dias, sendo sete dias para adaptação dos animais, sete dias para determinação do consumo de matéria seca e quatro dias para coleta de amostras. As coletas foram feitas através de fístula ruminal nos tempos zero, dois, quatro e seis horas após a alimentação, sendo utilizadas para determinações das concentrações de amônia, pH e AGV do líquido ruminal. Não houve interações entre o fubá de milho e o farelo de soja, assim como não ocorreu efeito do tempo de coleta sobre os parâmetros estudados. O farelo de soja reduziu a relação acetato:propionato (A:P) em 13\%, aumentou o consumo de matéria seca total (CMSt) em 41,2\%, sem alterar o consumo de forragem e o $\mathrm{pH}$, e aumentou as concentrações de amônia (790\%), propionato (48\%), AGV total (39\%), isobutirato (165\%), isovalerato (208\%) e valerato (201\%). O fubá de milho não afetou a fermentação de proteína, embora tenha causado aumento no CMSt $(35 \%)$ e decréscimo no $\mathrm{pH}$ ruminal $(6 \%)$ e na relação A:P $(18 \%)$.
\end{abstract}

Palavras-chave: amônia, consumo, desaminação, $\mathrm{pH}$, proteína, suplementação

\section{Feed Intake and Ruminal Fermentation of Proteins as a Function of Energetic and Proteic Food Supplementation of Steers}

\begin{abstract}
The objective was to evaluate the effect of energetic supplementation on feed intake and ruminal fermentation of proteins in two protein levels in the diet ( 6 and 20\%). There were used four rumen fistulated crossbred steers in a Latim square and the treatments were arranjed in a $2 \times 2$ factorial, in which the combinations were: A. only hay; B. hay $+2.8 \mathrm{~kg}$ of soybean meal; C. hay $+2.8 \mathrm{~kg}$ of corn meal; and D. hay $+2.8 \mathrm{~kg}$ of soybean meal $+2.8 \mathrm{~kg}$ of corn meal. Four experimental periods of 18 days were used, in which seven was for adaptation, seven for determination of dry matter intake and four for sampling. Ruminal samples were collected at $0,2,4$ and 6 hours after feeding for determination of ammonia, $\mathrm{pH}$ and VFA. There was no interaction between corn meal and soybean meal, as well as no sampling time effect on the evaluated parameters. Soybean meal decreased 13\% acetate:propionate (A:P) ratio and increased $41.2 \%$ DMI, with no effect on forage intake and $\mathrm{pH}$ and increased ammonia (790\%), propionate (48\%), total VFA (39\%), isobutyrate (165\%), isovalerate (208\%) and valerate (201\%). Corn meal did not affect protein fermentation, although it caused increase in DMI (35\%) and decrease in ruminal $\mathrm{pH}(6 \%)$ and $\mathrm{A}: \mathrm{P}$ ratio $(18 \%)$.
\end{abstract}

Key Words: ammonia, deamination, intake, $\mathrm{pH}$, protein, supplementation

\section{Introdução}

Em dietas à base de forragens de baixa qualidade, o consumo total de nutrientes geralmente aumenta pela adição de suplementos concentrados, melhorando, assim, o desempenho dos animais. Os efeitos do suplemento sobre o consumo de matéria seca podem ser aditivos, quando o consumo de suplemento se agrega ao consumo atual do animal; substitutivos, quando o consumo de suplemento diminui o consumo de forragem, sem melhorar o desempenho do animal; aditivos/substitutivos, onde ocorrem ambos procedimentos anteriores, com substituição do volumoso e melhora do desempenho do animal, e que geralmente ocorre com suplementação energética; aditivos com estímulo, em que o consumo de suplemento estimula o consumo de forragem, normalmente em alimentos protéicos, pois esses favorecem a ação dos microrga-

\footnotetext{
1 Parte da tese de Mestrado do primeiro autor.

2 Estudante de Mestrado em Zootecnia - UFV - 36.571-000 - Viçosa - MG; Bolsista da CAPES

3 Professor do Departamento de Zootecnia - UFV - 36.571-000 - Viçosa - MG - Bolsista do CNPq. E-mail: rlana@mail.ufv.br

4 Professor do Departamento de Química - UFV - 36.571-000 - Viçosa - MG.

5 Professor do Departamento de Microbiologia - UFV - 36.571-000 - Viçosa - MG.

${ }^{6}$ Estudante de Zootecnia - UFV; Bolsista de Iniciação Científica - FAPEMIG.
} 
nismos; ou ainda os substitutivos com redução, nos quais o consumo de forragem e o desempenho do animal são ambos reduzidos (LANGE, 1980).

A suplementação protéica é necessária para corrigir a deficiência de nitrogênio das pastagens, principalmente no período da seca, maximizando a eficiência de crescimento microbiano e estimulando a digestibilidade e o consumo das mesmas. A proteína, entretanto, onera o custo da ração, sendo essencial o conhecimento do seu uso de maneira adequada para minimizar as perdas por fermentação ruminal (RUSSELL, 1996). As perdas podem ocorrer pela desaminação de aminoácidos por bactérias e protozoários ruminais, causando acúmulo de amônia no rúmen e excreção de uréia na urina. A excreção de uréia causa perda energética, diminuição da eficiência de utilização do nitrogênio alimentar e contaminação do solo e cursos d'água nas proximidades das regiões criatórias de bovinos em condições intensivas, onde ocorre a maior concentração de nitrogênio (YECK et al., 1975; NOLAN et al., 1976).

A manipulação da fermentação ruminal tem sido empregada para aumentar a produtividade animal e reduzir as perdas por fermentações indesejáveis. No caso do metabolismo das proteínas, isto pode ser feito com uso de fontes de proteína com menor degradabilidade ruminal, mas de boa qualidade; uso de maior quantidade de proteína degradada em rações, quando há maior disponibilidade de carboidratos mais facilmente degradáveis (SNIFFEN et al., 1992); uso de ionóforos como a monensina (LANA e RUSSELL, 1997); uso de aminoácidos protegidos, dentre outros.

Níveis elevados de suplementos energéticos à base de grãos, ricos em amido, podem reduzir a digestibilidade do volumoso pelo abaixamento do $\mathrm{pH}$ ruminal (COELHO e LEÃO, 1979; HOOVER e STOKES, 1991). Entretanto, ERFLE et al. (1982) verificaram decréscimo na produção de amônia, quando o $\mathrm{pH}$ variou de 7,0 a 5,0, provavelmente associado à perda de organismos proteolíticos. Neste caso, ao contrário do efeito negativo do $\mathrm{pH}$ sobre a degradabilidade da fibra, o decréscimo da atividade proteolítica ruminal apresenta como possível benefício o aumento da proteína dietética escapando à degradação ruminal.

LANA et al. (1998) demonstraram que, em uma redução do $\mathrm{pH}$, in vitro, de 6,5 para 5,7 , houve diminuição na produção de amônia em bactérias de animais recebendo dietas contendo apenas forragem, enquanto que, em bactérias de animais recebendo $90 \%$ de concentrado, houve uma produção similar de amônia nos dois diferentes pHs. Estes resultados demonstram que as populações microbianas desaminadoras de aminoácidos são distintas nos dois diferentes ambientes ruminais. No $\mathrm{pH}$ elevado, as bactérias desaminadoras são mais capacitadas a desaminar aminoácidos e são favorecidas pelo $\mathrm{pH}$ do meio, mas são pouco tolerantes ao abaixamento do $\mathrm{pH}$.

Este trabalho visou verificar o efeito da suplementação de fubá de milho (fonte energética) e farelo de soja (fonte protéica) na ração de novilhos sobre o consumo de alimentos, fermentação ruminal e atividades proteolítica e desaminadora in vitro, utilizando o monitoramento da produção de amônia.

\section{Material e Métodos}

\section{Localização}

O experimento foi conduzido no Laboratório de Nutrição Animal do Departamento de Zootecnia da Universidade Federal de Viçosa, UFV, Minas Gerais. As análises laboratoriais foram realizadas no Laboratório de Anaeróbios do Departamento de Microbiologia, UFV, e no Laboratório de Pesquisas em Produtos Naturais do Departamento de Química, UFV.

A cidade de Viçosa localiza-se na Zona da Mata do Estado de Minas Gerais, a $20^{\circ} 45^{\prime}$ de Latitude Sul e 42 51 ' de Longitude Oeste e a altitude de $649 \mathrm{~m}$. De acordo com dados fornecidos pelo Departamento de Engenharia Agrícola da Universidade Federal de Viçosa, o clima de Viçosa é subtropical, com inverno frio e seco e verão quente e úmido, sendo classificado como Cwa subtropical. Apresenta precipitação pluviométrica anual média de $1342 \mathrm{~mm}$, sendo que $80 \%$ das chuvas caem entre os meses de outubro a março, período chuvoso, e os $20 \%$ restantes entre os meses de abril a setembro, período seco. Possui temperatura média das máximas de $26,1^{\circ} \mathrm{C}$, e das mínimas de $14^{\circ} \mathrm{C}$, com umidade relativa do ar de $80 \%$.

\section{Animais e tratamentos}

Foram utilizados quatro novilhos mestiços, com peso médio inicial de $420 \mathrm{~kg}$, fistulados no rúmen. Os animais foram mantidos constantemente presos por cordas, em baias com piso de concreto, e comedouros e bebedouros individuais. O experimento constituiu-se de quatro períodos de 18 dias, sendo sete dias para adaptação dos animais, sete dias para determinação do consumo de matéria seca e quatro dias para coleta de 
amostras, distribuídos em um quadrado latino $4 \times 4$.

As dietas testadas foram as seguintes: a) somente feno; b) feno $+2,8 \mathrm{~kg}$ de farelo de soja; c) feno $+2,8 \mathrm{~kg}$ de fubá de milho; e d) feno $+2,8 \mathrm{~kg}$ de farelo de soja $+2,8 \mathrm{~kg}$ de fubá de milho. O feno utilizado foi de capim elefante picado e seco em um secador de café, sendo fornecido ad libitum aos animais. A dieta foi fornecida uma vez ao dia, pela manhã, e a água foi fornecida continuamente ad libitum.

Manejo, coleta de dados, análises bromatológicas e composição dos alimentos

Os animais foram pesados no início e no final do experimento. Diariamente, nos períodos de adaptação e de coletas, foram feitas pesagens do feno, do concentrado oferecido e das sobras. O feno e os concentados foram amostrados em cada período e estocados em sacos plásticos, devidamente identificados para posteriores análises laboratoriais.

Os teores de matéria seca (MS) foram determinados por secagem em estufa a $105^{\circ} \mathrm{C}$, até peso constante. A cinza foi obtida por meio da incineração de, aproximadamente, $1 \mathrm{~g}$ de amostra em mufla a $600^{\circ} \mathrm{C}$, durante quatro horas. A matéria orgânica (MO) foi obtida subtraindo-se os teores de cinza na MS de 100. O nitrogênio (N) total foi estimado pelo método semi-micro Kjeldahl, obtendo-se valores de proteína bruta, multiplicando-se o $\mathrm{N}$ total pelo fator 6,25. A fibra em detergente neutro (FDN) foi determinada, segundo metodologia de Van Soest, 1967, citado por SILVA (1990).

Na Tabela 1 encontram-se a composição dos alimentos e na Tabela 2, a composição das dietas experimentais.

Determinação da atividade específica de produção de amônia pelos microrganismos ruminais

Nos dias um e dois de cada período experimental foram realizadas coletas do líquido ruminal duas vezes por semana, três horas após o fornecimento da dieta. O material coletado preencheu um erlenmeyer de $0,25 \mathrm{~L}$, sendo imediatamente fechado para conservação da anaerobiose. O material foi transportado a $39^{\circ} \mathrm{C}$ para o Laboratório e centrifugado anaerobicamente a $500 \times \mathrm{g}\left(3 \mathrm{~min}, 25^{\circ} \mathrm{C}\right)$, para eliminação das partículas alimentares e dos protozoários. A concentração de proteína bacteriana foi determinada em duplicata, centrifugando-se 1,5 $\mathrm{mL}$ do líquido sobrenadante a $13.000 \times \mathrm{g}$, por 10 min, seguido de sucessivas ressuspensões e centrifugações do sedimento bacteriano em solução de $\mathrm{NaCl}$ a $0,9 \%$ (p/v), e em seguida, uma alíquota de $1,5 \mathrm{~mL}$ foi armazenada a $-15^{\circ} \mathrm{C}$ para posterior análise.

Foram transferidos em duplicata para tubos de incubação, $9 \mathrm{~mL}$ do líquido sobrenadante da centrifugação a $500 \times \mathrm{g}$, preenchidos com $\mathrm{CO}_{2} \mathrm{e}$ vedados com rolha de borracha. No tempo zero, 1,0 mL de uma solução anaeróbica de tripticase (BBL Microbiology Systems, Cockeysville, MD) foi adicionada aos tubos ( $15 \mathrm{~g} / \mathrm{L}$ de concentração final), procedendo-se então à incubação a $39^{\circ} \mathrm{C}$ por quatro horas. No início e no final da incubação, $1,5 \mathrm{~mL}$ do meio foi centrifugado $(13.000 \times \mathrm{g}, 10 \mathrm{~min})$ para remoção das bactérias. O líquido sobrenadante foi

Tabela 1 - Composição bromatológica dos ingredientes utilizados, expressa na base da matéria seca Table 1 - Chemical composition of the food sources, in dry matter basis

\begin{tabular}{|c|c|c|c|c|c|c|}
\hline \multirow[b]{2}{*}{$\begin{array}{l}\text { Componente }^{1} \\
\text { Component }^{1}\end{array}$} & \multicolumn{4}{|c|}{$\begin{array}{l}\text { Feno } \\
\text { Hay }\end{array}$} & \multirow[b]{2}{*}{$\begin{array}{c}\text { Fubá de milho } \\
\text { Corn meal }\end{array}$} & \multirow[b]{2}{*}{$\begin{array}{c}\text { Farelo de soja } \\
\text { Soybean meal }\end{array}$} \\
\hline & $\mathrm{I}$ & II & II & IV & & \\
\hline $\mathrm{MS}(D M)(\%)$ & 87,76 & 88,94 & 88,59 & 88,62 & 84,05 & 86,11 \\
\hline $\mathrm{PB}(C P)(\%)$ & 5,03 & 5,99 & 5,15 & 4,68 & 10,36 & 53,53 \\
\hline FDN $(N D F)(\%)$ & 80,85 & 78,55 & 78,45 & 82,03 & 22,81 & 14,73 \\
\hline $\mathrm{FDA}(A D F)(\%)$ & 49,31 & 52,64 & 49,37 & 54,39 & 3,13 & 8,85 \\
\hline Hemicel $(\%)$ & 31,54 & 25,91 & 29,09 & 27,64 & 19,69 & 5,89 \\
\hline $\operatorname{Cel}(\%)$ & 40,00 & 28,61 & 40,58 & 43,86 & 2,54 & 7,75 \\
\hline $\operatorname{Lig}(\%)$ & 9,24 & 10,63 & 7,77 & 9,70 & 0,47 & 1,06 \\
\hline Cinzas $(A s h)(\%)$ & 0,06 & 0,16 & 1,01 & 0,83 & 0,12 & 0,04 \\
\hline $\mathrm{Ca}(\%)$ & 0,36 & 0,29 & 0,35 & 0,37 & 0,02 & 0,23 \\
\hline$P(\%)$ & 0,12 & 0,15 & 0,15 & 0,18 & 0,25 & 0,27 \\
\hline
\end{tabular}

${ }^{1} \mathrm{MS}=$ matéria seca; $\mathrm{PB}=$ proteína bruta; FDN = fibra em detergente neutro; FDA = fibra em detergente ácido; Hemicel = hemicelulose; Cel = celulose $;$ Lig = lignina; $\mathrm{Ca}=$ cálcio; $\mathrm{P}=$ fósforo.

${ }^{1} D M=$ dry matter; $C P=$ crude protein; NDF = neutral detergent fiber; $A D F=$ acid detergent fiber; Hemicel = hemicellulose; Cel = cellulose; Lig = lignin; $\mathrm{Ca}=$ calcium; $P=$ phosphorus. 
Tabela 2 - Composição porcentual e bromatológica das dietas fornecidas aos animais, expressa na base da matéria seca Table 2 - Percentual and chemical composition of diets fed to the animals, in dry matter basis

\begin{tabular}{|c|c|c|c|c|}
\hline \multirow[b]{2}{*}{$\begin{array}{l}\text { Componente }^{1} \\
\text { Component }^{1}\end{array}$} & \multicolumn{4}{|c|}{$\begin{array}{c}\text { Dietas } \\
\text { Diets }\end{array}$} \\
\hline & $\begin{array}{l}\text { Controle } \\
\text { Control }\end{array}$ & $\begin{array}{l}\text { Fubá de milho } \\
\text { Corn meal }\end{array}$ & $\begin{array}{c}\text { Farelo de soja } \\
\text { Soybean meal }\end{array}$ & $\begin{array}{c}\text { Milho + farelo de soja } \\
\text { Corn + soybean meal }\end{array}$ \\
\hline Feno (Hay) (\%) & 100 & 68 & 67 & 50 \\
\hline $\mathrm{FM}(C M)(\%)$ & 0 & 32 & 0 & 25 \\
\hline $\mathrm{FS}(S B M)(\%)$ & 0 & 0 & 33 & 25 \\
\hline $\mathrm{PB}(C P)(\%)$ & 5,21 & 6,99 & 21,74 & 19,44 \\
\hline $\mathrm{FDN}(N D F)(\%)$ & 79,97 & 60,16 & 57,65 & 47,71 \\
\hline $\operatorname{FDA}(A D F)(\%)$ & 51,43 & 34,68 & 36,86 & 27,52 \\
\hline Hemicel( $(\%)$ & 28,54 & 25,47 & 20,79 & 20,20 \\
\hline Cel $(\%)$ & 38,26 & 25,88 & 27,82 & 20,84 \\
\hline $\operatorname{Lig}(\%)$ & 9,33 & 6,26 & 6,50 & 4,82 \\
\hline Cinzas $(A s h)(\%)$ & 0,51 & 0,38 & 0,35 & 0,28 \\
\hline $\mathrm{Ca}(\%)$ & 0,34 & 0,23 & 0,30 & 0,23 \\
\hline $\mathrm{P}(\%)$ & 0,15 & 0,18 & 0,18 & 0,20 \\
\hline
\end{tabular}

${ }^{1}$ Feno = feno de capim-elefante picado; FM = fubá de milho; FS = farelo de soja; $P B$ = proteína bruta; FDN = fibra em detergente neutro; FDA = fibra em detergente ácido; Hemicel = hemicelulose; $\mathrm{Cel}=$ celulose; $\mathrm{Lig}=$ lignina; $\mathrm{Ca}=$ cálcio; $\mathrm{P}=$ fósforo.

${ }_{1}^{1}$ Hay = chopped elephantgrass hay; $C M=$ corn meal; $S B M=$ soybean meal; $C P=$ crude protein; $N D F=$ neutral detergent fiber; $A D F=$ acid detergent fiber; Hemicel $=$ hemicellulose $; \mathrm{Cel}=$ cellulose $; \mathrm{Lig}=$ lignin $; \mathrm{Ca}=$ calcium; $P=$ phosphorus.

armazenado separadamente a $-15^{\circ} \mathrm{C}$ para mensuração de amônia.

As concentrações de amônia foram determinadas segundo o método de CHANEY e MARBACH (1962). As análises de proteína bacteriana foram feitas segundo o método de LOWRY et al. (1951). Ambos os métodos são baseados em colorimetria, utilizando-se espectrofotômetro com os comprimentos de onda de 630 e $660 \mathrm{~nm}$, respectivamente.

A atividade específica de produção de amônia (AEPA) ou atividade de desaminação pelos microrganismos ruminais foi determinada, medindo-se a quantidade de amônia produzida por mg de proteína microbiana por minuto.

Determinação do pH, amônia e ácidos graxos voláteis ruminais

Cerca de $100 \mathrm{~mL}$ de líquido ruminal foram removidos a partir de cada animal, quatro vezes ao dia (zero, duas, quatro e seis horas após a alimentação), no terceiro e quarto dias de cada período experimental. O conteúdo retirado foi filtrado por meio de quatro camadas de gaze e depositado em frascos vedados. A amostra coletada de líquido ruminal foi resfriada com gelo e água a cerca de $5^{\circ} \mathrm{C}$ e transportada até o Laboratório, procedendo-se à leitura do $\mathrm{pH}$. O líquido $(1,5 \mathrm{~mL})$ foi centrifugado a 12.000 r.p.m., por 10 minutos, e o sobrenadante congelado ($15^{\circ} \mathrm{C}$ ) para determinação de amônia e ácidos graxos voláteis $(\mathrm{AGV})$.
As análises de $\mathrm{AGV}$ no líquido de rúmen foram realizadas por meio da técnica de cromatografia de fase gasosa. As informações sobre as técnicas utilizadas para análise de cromatografia gasosa em líquido de rúmen são escassas e, quando existentes, relatam técnicas utilizadas em equipamentos obsoletos, e por isso houve a necessidade de se desenvolver uma metodologia própria.

As amostras do líquido centrifugado foram diluídas na proporção de $500 \mu \mathrm{L}$ para $500 \mu \mathrm{L}$ de ácido fosfórico (25\%), centrifugadas a $13.000 \mathrm{rpm}$ por 20 minutos, até que as alíquotas ficassem totalmente livres de impurezas, devido à sensibilidade do equipamento.

O padrão utilizado para o cálculo das concentrações de AGV nas amostras foi preparado da seguinte forma: em um balão volumétrico de $50 \mathrm{~mL}$, completou-se $49,5 \mathrm{~mL}$ com ácido fosfórico a $25 \%$ e pipetouse $171 \mu \mathrm{L}$ de ácido acético, $149 \mu \mathrm{L}$ de ácido propiônico, $138 \mu \mathrm{L}$ de ácido butírico, $23 \mu \mathrm{L}$ de ácido isobutírico, $27 \mu \mathrm{L}$ de ácido isovalérico e $27 \mu \mathrm{L}$ de ácido valérico, para se obter as concentrações finais dos padrões equivalentes a $60 \mathrm{mM}$ (mili molar) de ácido acético, $40 \mathrm{mM}$ de ácido propiônico, $30 \mathrm{mM}$ de ácido butírico e $5 \mathrm{mM}$ para cada um dos demais ácidos. Os padrões possuíam graus de pureza específicos para cromatografia gasosa.

A coluna utilizada foi a Nukol da Supelco. Os parâmetros do equipamento foram: temperatura inicial de $100^{\circ} \mathrm{C}$ e final de $200^{\circ} \mathrm{C}$ para a coluna, 220 e 
$240^{\circ} \mathrm{C}$ para o injetor, 250 e $270^{\circ} \mathrm{C}$ para o detector de ionização de chama. O modelo para controle foi determinado por split, a pressão da coluna foi de $150 \mathrm{kPA}$, o fluxo da coluna de $1906,47 \mathrm{~mL} / \mathrm{min}$, a velocidade linear de $43.228 \mathrm{~cm} / \mathrm{s}$, o fluxo total de 158 $\mathrm{mL}$, a largura de $30 \mathrm{~m}$ e o diâmetro da coluna de 0,25 $\mathrm{mm}$. Os cálculos foram realizados através da área onde o método adotado foi o de normalização correta. O método do quadrado mínimo foi utilizado para determinar o tipo de aproximação da curva onde obteve-se uma identificação absoluta.

\section{Análises estatísticas}

Os dados do experimento foram analisados em quadrado latino $4 \times 4$. Cada animal em cada período correspondeu a uma unidade experimental. O modelo estatístico incluiu os efeitos de animais, períodos e tratamentos. Os tratamentos foram analisados em esquema fatorial $2 \times 2$, determinando-se os efeitos principais e de interação. $\mathrm{Na}$ análise do $\mathrm{pH}$, ácidos graxos voláteis e amônia ruminais, incluiu-se os efeitos de tempo de coleta das amostras e interação tempo*tratamento em parcela subdividida.

\section{Resultados e Discussão}

Não houve efeito de interação (fubá de milho $\times$ farelo de soja) para nenhuma das variáveis estudadas $(\mathrm{P}>0,10)$. O fubá de milho aumentou o consumo de

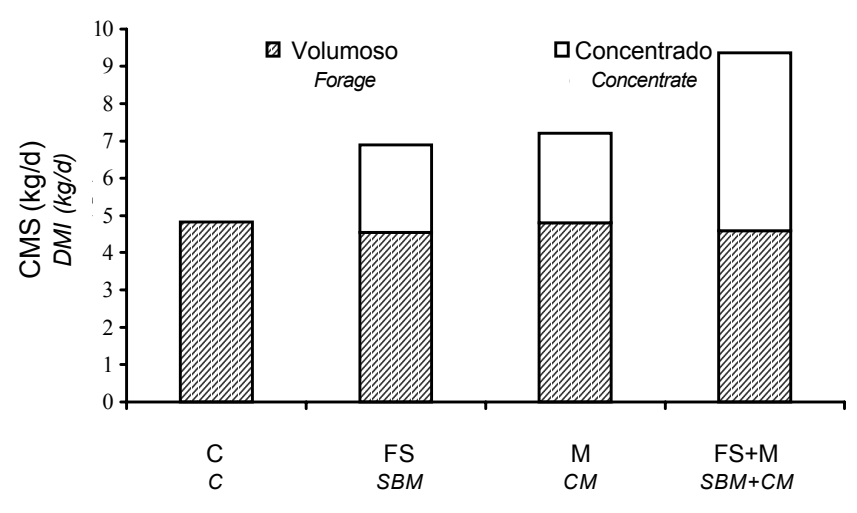

Figura 1 -Consumo de matéria seca (volumoso e concentrado) por novilhos com $420 \mathrm{~kg}$ de peso corporal, recebendo feno de capim-elefante com ou sem 2,8 kg de farelo de soja (FS) e, ou, 2,8 kg de fubá de milho (M).

Figure 1 - Dry matter intake (forage and concentrate) by steers with $420 \mathrm{~kg}$ body weight, receiving Elephant-grass hay with or without $2.8 \mathrm{~kg}$ of soybean meal (SBM) and, or, $2.8 \mathrm{~kg}$ of corn meal (CM). matéria seca total $(\mathrm{CMSt})$ em $35 \%(\mathrm{P}<0,01)$, e o farelo de soja em $41,2 \%(P<0,01)$, ambos sem efeito sobre o consumo de forragem $(\mathrm{P}>0,10)$ (Figura $1 \mathrm{e}$ Tabela 3). Ocorreu, portanto, efeito aditivo dos suplementos no consumo de matéria seca, pois houve estímulo no CMSt, sem afetar o consumo de volumoso.

O tempo de coleta do líquido de rúmen (zero, dois, quatro e seis horas pós alimentação) não influenciou os parâmetros analisados, ou seja, não houve efeito de tempo nem interação tempo $\times$ tratamento. Desse modo, apenas foram reportados os dados médios observados.

O fubá de milho reduziu o pH ruminal em $6 \%$ $(\mathrm{P}<0,10)$. VARGAS JR. et al. (2000), ao trabalharem com grão de milho na alimentação de terneiros, não encontraram efeito do milho sobre a amônia e pH. Do mesmo modo, CALDAS NETO et al. (2000) não encontraram diferenças no $\mathrm{pH}$ do líquido ruminal em rações que continham milho, raspa de mandioca, farinha de varredura ou milho+casca de mandioca. FREGADOLLI et al. (2000) também não encontraram diferença em fontes de amido (casca de mandioca e milho) e nitrogênio (levedura e farelo de algodão+farinha de carne e ossos) de alta ou baixa degradabilidade.

O farelo de soja causou um aumento acentuado (790\%) na concentração de amônia $(\mathrm{P}<0,01)$, observado também por DETMANN et al. (2000), em suplementação a campo para bovinos em terminação contendo $20 \%$ de PB. Não foi observado efeito de tratamento sobre a atividade específica de produção de amônia e proteína microbiana (Tabela 3).

Esperava-se redução no nível de amônia pela adição de milho, uma vez que a mesma seria utilizada na síntese de proteína microbiana (ANNISON, 1956), ou sua produção seria inibida pela redução do $\mathrm{pH}$ ruminal. ERFLE et al. (1982) encontraram uma redução na produção de amônia, assim como uma menor concentração de aminoácidos livres e redução de atividade proteolítica e desaminadora em resposta à redução do pH inicial de 6,0-7,0 para 5,5-5,0 em experimento in vitro, utilizando concentrado peletizado e silagem de milho.

Efeitos do pH sobre a produção de amônia foram também observados por LANA et al. (1998) in vitro e in vivo e por CUNHA et al. (2000), em que o $\mathrm{pH}$ apresentou maior correlação com a produção de amônia in vitro que a presença de amido. Entretanto, na atual pesquisa, a falta de efeito foi provavelmente devida à pequena variação de $\mathrm{pH}$ observada no 
presente experimento $(6,28$ a 6,63), ao contrário daquela relatada por LANA et al. (1998), que variou de 5,7 a 6,5 .

O fubá de milho não afetou as concentrações dos ácidos graxos voláteis $(\mathrm{P}>0,10)$, mas reduziu a relação acetato:propionato em 18\% (Tabela 4). Este efeito normalmente ocorre pelo aumento da proporção molar de propionato e concomitante redução da produção de acetato e butirato (VAN NEVEL e DEMEYER, 1988), devido ao aumento da população microbiana amilolítica, especializada na produção de propionato.

$\mathrm{O}$ farelo de soja aumentou $(\mathrm{P}<0,10)$ a concentração de propionato (48\%) e a de AGV total (39\%), aumentou $(\mathrm{P}<0,05)$ as concentrações dos ácidos graxos isobutírico (165\%), isovalérico (208\%) e valérico (201\%), e reduziu a relação acetato:propionato (13\%)

Tabela 3 - Consumo da matéria seca total (CMSt), consumo de forragem (Cforr), $\mathrm{pH}$, amônia ruminal $\left(\mathrm{NH}_{3}\right)$, atividade específica de produção de amônia (AEPA) e proteína microbiana no líquido de rúmen centrifugado (PM) em novilhos recebendo feno de capim-elefante com ou sem $2,8 \mathrm{~kg}$ de fubá de milho e $2,8 \mathrm{~kg}$ de farelo de soja

Table 3 - Total dry matter intake (CMSt), forage intake (Cforr), $\mathrm{pH}$, ruminal ammonia $\left(\mathrm{NH}_{3}\right)$, specific activity of ammonia production (SAAP) and microbial protein in centrifuged ruminal fluid $(P M)$ of steers receiving elephantgrass hay, with or without $2.8 \mathrm{~kg}$ of corn meal and $2.8 \mathrm{~kg}$ of soybean meal

\begin{tabular}{|c|c|c|c|c|c|}
\hline \multirow[b]{2}{*}{ Item } & \multicolumn{2}{|c|}{$\begin{array}{l}\text { Fubá de milho } \\
\text { Corn meal }\end{array}$} & \multicolumn{2}{|c|}{$\begin{array}{l}\text { Farelo de soja } \\
\text { Soybean meal }\end{array}$} & \multirow[t]{2}{*}{$\begin{array}{c}\mathrm{EP}^{1} \\
\mathrm{SE}\end{array}$} \\
\hline & 0 & 2,8 & 0 & 2,8 & \\
\hline CMSt, $\mathrm{kg} / \mathrm{d}$ & $6,02^{\mathrm{a}}$ & $8,12^{\mathrm{b}}$ & $5,86^{\mathrm{a}}$ & $8,28^{b}$ & 0,29 \\
\hline Cforr, $\mathrm{kg} / \mathrm{d}$ & 4,82 & 4,57 & 4,69 & 4,69 & 0,29 \\
\hline $\mathrm{pH}$ & $6,64^{\mathrm{A}}$ & $6,27^{\mathrm{B}}$ & 6,52 & 6,39 & 0,10 \\
\hline $\mathrm{NH}^{3}, \mathrm{mM}$ & 9,23 & 8,68 & $1,81^{\mathrm{a}}$ & $16,1^{b}$ & 2,79 \\
\hline $\mathrm{AEPA}^{2}$ & 86,2 & 70,9 & 76,4 & 80,8 & 37,2 \\
\hline$S A A P$ & & & & & \\
\hline $\mathrm{PM}, \mathrm{mg} / \mathrm{L}$ & 373,0 & 354,0 & 301,0 & 426,0 & 85,2 \\
\hline
\end{tabular}

${ }^{1}$ EP $=$ erro-padrão.

$2 \mathrm{AEPA}=$ nmol $\mathrm{NH}_{3} / \mathrm{mg}$ de proteína microbiana/minuto.

Médias seguidas por letras minúsculas ou maiúsculas difererentes, na mesma linha, para fubá de milho ou farelo de soja, diferem a $5 \%$ ou $10 \%$, respectivamente, pelo teste $\mathrm{F}$.

$1 \mathrm{SE}=$ standard error .

$2 \mathrm{SAAP}=\mathrm{nmol} \mathrm{NH}_{3} / \mathrm{mg}$ of microbial protein/minute.

Means followed by different regular or capital letters, in the same row, for corn meal or soybean meal, differ at 5 or $10 \%$, respectively, by $F$ test.
(Tabela 4). O aumento na produção de $\mathrm{AGV}$ pode ser atribuído ao aumento do nível de concentrado, que resultou em maior atividade microbiana sobre os carboidratos não fibrosos, e pelo estímulo à digestão da fibra devido ao suprimento de nitrogênio ao rúmen.

A adição do farelo de soja à dieta causou aumento significativo dos ácidos graxos voláteis de cadeia ramificada (AGVCR), como os ácidos isobutírico e isovalérico. Este fato evidencia a ocorrência de alta taxa de desaminação de aminoácidos no rúmen (Tabela 5 e Figura 2), em que se verifica alta correlação entre os AGVCR e o nível de amônia ruminal. Contudo, não houve efeito sobre o ácido butírico, que, ao contrário, foi o único ácido alterado em bezerros recebendo leite em pó reconstituído e feno, em diferentes idades (COELHO et al., 2000).

Tabela 4 - Concentração média de acetato, propionato, butirato, isobutirato, isovalerato, valerato, AGV total e relação acetato:propionato $(A: P)$ em novilhos recebendo feno de capim-elefante com ou sem 2,8 $\mathrm{kg}$ de fubá de milho e $2,8 \mathrm{~kg}$ de farelo de soja

Table 4 - Mean concentration of acetate, propionate, butyrate, isobutyrate, isovalerate, valerate, total VFA and acetate:propionate ratio $(A: P)$ of steers receiving elephantgrass hay, with or without $2.8 \mathrm{~kg}$ of corn meal and $2.8 \mathrm{~kg}$ of soybean meal

\begin{tabular}{|c|c|c|c|c|c|}
\hline \multirow[b]{2}{*}{ Item } & \multicolumn{2}{|c|}{$\begin{array}{c}\text { Fubá de milho } \\
\text { Corn meal }\end{array}$} & \multicolumn{2}{|c|}{$\begin{array}{c}\text { Farelo de soja } \\
\text { Soybean meal }\end{array}$} & \multirow[t]{2}{*}{$\begin{array}{l}\mathrm{EP} \\
S E^{1}\end{array}$} \\
\hline & 0 & 2,8 & 0 & 2,8 & \\
\hline $\begin{array}{l}\text { Acetate, } \mathrm{mM} \\
\text { Acetate }\end{array}$ & 58,2 & 57,1 & 51,0 & 64,3 & 5,22 \\
\hline $\begin{array}{l}\text { Propionato, } \mathrm{mM} \\
\text { Propionate }\end{array}$ & 15,1 & 18,6 & $13,6^{\mathrm{A}}$ & $20,1^{\mathrm{B}}$ & 21,98 \\
\hline $\begin{array}{l}\text { Butirato, } \mathrm{mM} \\
\text { Butyrate }\end{array}$ & 6,46 & 8,87 & 5,65 & 9,68 & 1,71 \\
\hline $\begin{array}{l}\text { Isobutirato, } \mathrm{mM} \\
\text { Isobutyrate }\end{array}$ & 1,21 & 1,28 & $0,68^{\mathrm{a}}$ & $1,81^{b}$ & 0,18 \\
\hline $\begin{array}{l}\text { Isovalerato, } \mathrm{mM} \\
\text { Isovalerate }\end{array}$ & 2,07 & 2,27 & $1,06^{\mathrm{a}}$ & $3,28^{b}$ & 0,46 \\
\hline $\begin{array}{l}\text { Valerato, } \mathrm{mM} \\
\text { Valerate }\end{array}$ & 1,19 & 1,53 & $0,68^{\mathrm{a}}$ & $2,04^{b}$ & 0,30 \\
\hline $\begin{array}{l}\text { AGV total, } \mathrm{mM} \\
\text { Total VFA }\end{array}$ & 84,3 & 89,7 & $72,7^{\mathrm{A}}$ & $101,2^{\mathrm{B}}$ & 9,64 \\
\hline$A: P$ & $3,95^{\mathrm{a}}$ & $3,24^{b}$ & $3,85^{\mathrm{a}}$ & $3,34^{\mathrm{b}}$ & 0,16 \\
\hline
\end{tabular}

${ }^{1} \mathrm{EP}=$ erro-padrão.

Médias seguidas por letras minúsculas ou maiúsculas difererentes, na mesma linha, para fubá de milho ou farelo de soja, diferem a $5 \%$ ou $10 \%$, respectivamente, pelo teste $\mathrm{F}$.

1 SE $=$ standard error .

Means followed by different regular or capital letters, in the same row, for corn meal or soybean meal, differ at 5 or $10 \%$, respectively, by $F$ test. 
Tabela 5 - Correlações entre AGV total, isobutirato, isovalerato, amônia $\left(\mathrm{NH}_{3}\right)$, proteína microbiana (PM), farelo de soja (FS) e fubá de milho (FM)

Table 5 - Correlations among total VFA, isobutyrate, isovalerate, ammonia (NH$H_{3}$ ), microbial protein (MP), soybean meal (SBM) and corn meal (CM)

\begin{tabular}{lcccccc}
\hline & $\begin{array}{c}\mathrm{AGV} \text { total } \\
\text { Total } V F A\end{array}$ & $\begin{array}{c}\text { Isobutirato } \\
\text { Isobutyrate }\end{array}$ & $\begin{array}{c}\text { Isovalerato } \\
\text { Isovalerate }\end{array}$ & $\mathrm{NH}_{3}$ & $\mathrm{PM}$ & $\mathrm{FS}$ \\
& $0,83^{* *}$ & & & & & \\
Isobutirato & $0,88^{* *}$ & $0,98^{* *}$ & & & & \\
Isovalerato & $0,79^{* *}$ & $0,95^{* *}$ & $0,96^{* *}$ & & & \\
$\mathrm{NH}_{3}(\mathrm{mM})$ & $0,74^{* *}$ & $0,66^{* *}$ & $0,70^{* *}$ & $0,69^{* *}$ & & \\
$\mathrm{PM}(M P)(\mathrm{mg} / \mathrm{L})$ & $0,54^{*}$ & $0,83^{* *}$ & $0,77^{* *}$ & $0,84^{* *}$ & 0,37 & \\
$\mathrm{FS}(S B M(\mathrm{~kg} / \mathrm{an} / \mathrm{d})$ & 0,10 & 0,05 & 0,07 & $-0,030$ & $-0,06$ & 0,00 \\
$\mathrm{FM}(C M)(\mathrm{kg} / \mathrm{an} / \mathrm{d})$ & & & & &
\end{tabular}

** $e$ * Significativos a 1 e $5 \%$ de probabilidade.

${ }^{* *}$ and * Significant at 1 and $5 \%$ probability.
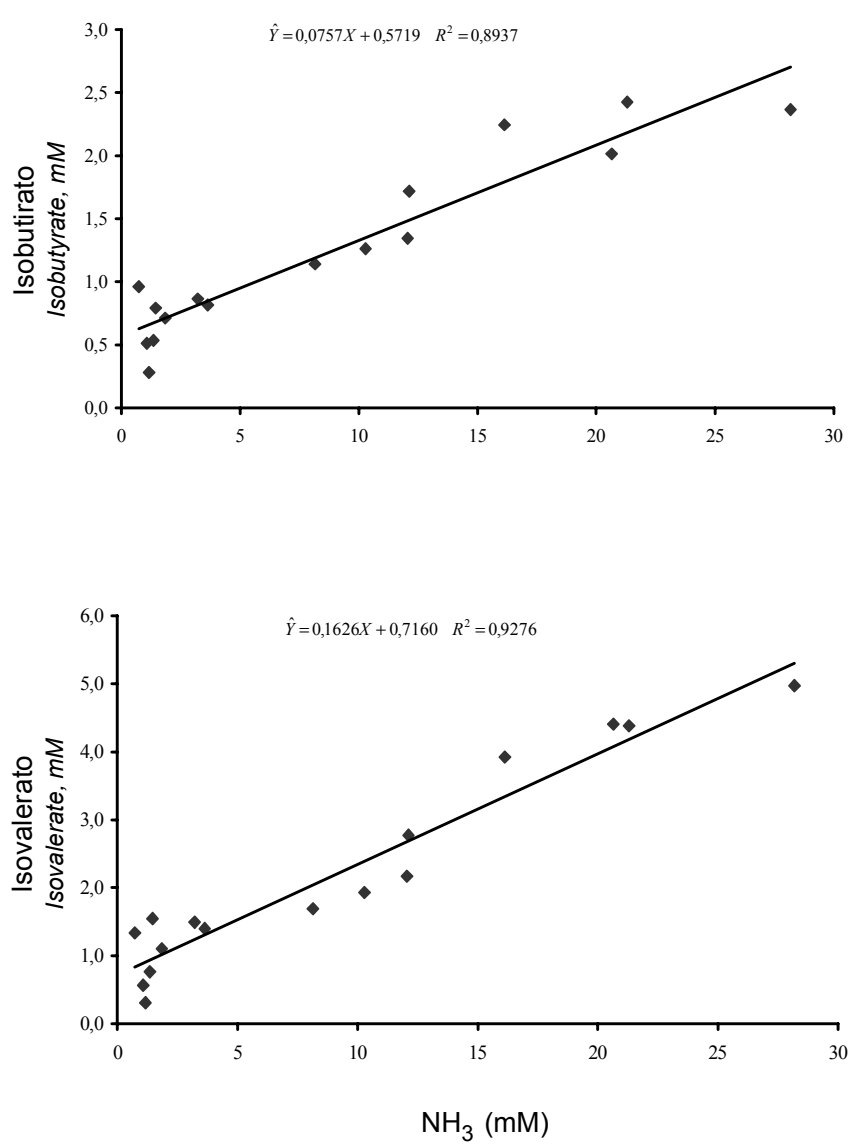

Figura 2 - Relações entre concentrações de isobutirato, isovalerato e amônia no líquido ruminal de novilhos recebendo feno de capim-elefante com ou sem 2,8 kg de farelo de soja (FS) e, ou, 2,8 kg de fubá de milho (FM).

Figure 2 - Relations among concentrations of isobutyrate, isovalerate and ammonia in rumen fluid of steers receiving elephantgrass hay with or without $2.8 \mathrm{~kg}$ of soybean meal and, or, $2.8 \mathrm{~kg}$ of corn meal.

\section{Conclusões}

Ocorreu um efeito aditivo dos suplementos sobre o consumo de matéria seca total, onde tanto o fubá de milho quanto o farelo de soja aumentaram-no, sem ocorrer efeito sobre o consumo de forragem.

O farelo de soja aumentou a concentração de amônia, concentração de $\mathrm{AGV}$ totais e $\mathrm{AGV}$ de cadeia ramificada, em vista da alta taxa de desaminação de aminoácidos no rúmen.

O fubá de milho reduziu o $\mathrm{pH}$, mas nenhum destes afetou a fermentação de proteínas pelos parâmetros analisados $\left(\mathrm{NH}_{3}\right.$ e atividade de desaminação).

\section{Referências Bibliográficas}

ANNISON, E.F. 1956. Nitrogen metabolism in the sheep. Biochem. J., 64:705-714.

CALDAS NETO, S.F., ZEOULA, L.M., BRANCO, A.F. et al. Mandioca e resíduos das farinheiras na alimentação de ruminantes: $\mathrm{pH}$, concentração de amônia e eficiência microbiana. In: REUNIÃO ANUAL DA SOCIEDADE BRASILEIRA DE ZOOTECNIA, 37, 2000, Viçosa, MG. Anais... Viçosa: SBZ, 2000, p.457.

CHANEY, A.L., MARBACH, E.P. 1962. Modified reagents for determination of urea and ammonia. Clin. Chem., 8:130-132.

COELHO DA SILVA, J.F., LEÃO, M.I. 1979. Fundamentos da nutrição dos ruminantes. Piracicaba: Livroceres. 384p.

COELHO, S.G., SATURNINO, H.M., OLIVEIRA, H.N. et al. Porcentagem molar de AGV do conteúdo ruminal até os 90 dias de idade, de bezerros desmamados aos 30 dias e alimentados com ou sem volumoso até 60 dias. In: REUNIÃO ANUAL DA SOCIEDADE BRASILEIRA DE ZOOTECNIA, 37, 2000, Viçosa, MG. Anais... Viçosa: SBZ, 2000. p. 473 .

CUNHA, L.T., LANA, R.P., BORGES, A.C. et al. The role of $\mathrm{pH}$ in regulating ammonia production by mixed ruminal bacteria. J. Anim. Sci., 78(Suppl. 1):289. 
DETMANN, E., PAUlinO, M.F., LANA, R.P. Fontes de proteína em suplementos múltiplos para terminação de bovinos em pastejo: $\mathrm{pH}$ e amônia ruminal. In: REUNIÃO ANUAL DA SOCIEDADE BRASILEIRA DE ZOOTECNIA, 37, 2000, Viçosa, MG. Anais... Viçosa: SBZ, 2000, p. 446 .

ERFLE, J.D., BOILA,R.J., TEATHER, R.M. et al. 1982. Effect of $\mathrm{pH}$ on fermentation characteristics and protein degradation by rumen microorganisms in vitro. J. Dairy Sci., 65:1457-1464.

FREGADOLLI, F.L., BRANCO, A.F., PRADO, I.N. et al. Efeito das fontes de amido e nitrogênio com diferentes degradabilidades ruminais sobre o $\mathrm{pH}$, concentração de amônia ruminal e eficiência de síntese microbiana. In: REUNIÃO ANUAL DA SOCIEDADE BRASILEIRA DE ZOOTECNIA, 37, 2000, Viçosa, MG. Anais... Viçosa: SBZ, 2000. p.419.

HOOVER, W.H., STOKES, S.R. 1991. Balancing carbohydrates and proteins for optimum rumen microbial yield. J. Dairy Sci., 74:363-3644.

LANA, R.P., RUSSELL, J.B. 1997. Effect of forage quality and monensin on the ruminal fermentation of fistulated cows fed continuously at a constant intake. J. Anim. Sci., 75:224-229.

LANA, R.P., RUSSELL, J.B., VAN AMBURGH, M.E. 1998. The role of $\mathrm{pH}$ in regulating ruminal methane and ammonia production. J. Anim. Sci., 76:2190-2196.

LANGE, A. 1980. Suplementación de pasturas para la producción de carnes. In: Colección Investigación Aplicada-Revista Crea.

LOWRY, O.H., ROSEBROUGH, N.J., FARR, A.L. et al. 1951. Protein measurement with the Folin phenol reagent. J. Biol. Chem., 193:265-275.

NOLAN, J.V., NORTON, B.W., LENG, R.A. 1976. Further studies of the dynamics of nitrogen metabolism in sheep. Br. J. Nutr., 35:127-147.

RUSSELL, J.B. 1996. Bacteria: Mechanisms of ionophore action in ruminal bacteria. In: 1996 Scientific Update on Rumensin/ Tylan/ Micotil for the professional feedlot consultant. Indianapolis: Elanco Animal Health. p.E1-E19.
SILVA, D.J. 1990. Análise de alimentos (métodos químicos e biológicos). Viçosa: UFV. 165 p.

SNIFFEN, C.J., O'CONNOR, J.D., VAN SOEST, P.J. et al. 1992. A net carbohydrate and protein system for evaluating cattle diets: II. Carbohydrate and protein availability. J. Anim. Sci., 70:3562-3577.

VAN NEVEL, C.J., DEMEYER, D.I. 1988. Manipulation of rumen fermentation. In: HOBSON, P.N. (Ed.) The rumen microbial ecosystem. Essex, England: Elsevier Science Publishers. p.387-443.

VARGAS JR., F.M., SANCHEZ, L.M.B., DIESEL, C.S. et al. Tratamento do grão de milho na alimentação de terneiros. IV. $\mathrm{N}$-amoniacal, $\mathrm{pH}$ e atividade bacteriana no fluído ruminal. In: REUNIÃO ANUAL DA SOCIEDADE BRASILEIRA DE ZOOTECNIA, 37, 2000, Viçosa, MG. Anais... Viçosa: SBZ, 2000, p.493.

YECK, R.G., SMITH, L.W., CALVERT, C.C. Recovery of nutrients from animal wastes. An overview of existing options and potentials for use in feed. In: PROC. 3RD INT. SYMP. LIVEST. WASTES, 1975, St. Joseph, MI. Proceedings... St. Joseph, MI: Am. Soc. Agric. Engineers. p.193-194. 